\title{
Antihyperglycemic activity of aqueous extract of leaves of Cocculus hirsutus (L.) Diels in alloxan-induced diabetic mice
}

\author{
S. Badole, N. Patel, S. Bodhankar, B. Jain, S. Bhardwaj ${ }^{\star}$
}

Department of Pharmacology, Poona College of Pharmacy, Bharati Vidyapeeth Deemed University, Erandwane, Pune-411 038 *Clinical Research, Serum Institute of India, Hadpsar, Pune-411 007. India

Received: 16.5.2005

Revised: 7.6.2005

Accepted: 23.11.2005

Correspondence to: Subhash Bodhankar E-mail: sbodh@yahoo.com

\begin{abstract}
Objective: To evaluate the antihyperglycemic activity of aqueous extract of leaves of Cocculus hirsutus (L.) Diels in alloxan-induced diabetic mice.

Materials and Methods: Alloxan-induced $(70 \mathrm{mg} / \mathrm{kg}$, i.v.) diabetic mice were given aqueous leaf extract $(250,500$, and $1000 \mathrm{mg} / \mathrm{kg}$, p.o., $n=6)$ of $C$. hirsutus or vehicle (distilled water, $10 \mathrm{ml} / \mathrm{kg}$, p.o.) or standard drug glyburide $(10 \mathrm{mg} / \mathrm{kg}$, p.o.) for 28 days. Blood samples were withdrawn by retro-orbital puncture and were analyzed for serum glucose on 0th, 7th, 14th, $21 \mathrm{st}$, and 28th days by glucose oxidase/peroxidase method. In oral glucose tolerance test, glucose (2.5 g/kg, p.o.) was administered to nondiabetic control, glyburide (10 mg/kg, p.o.), and aqueous extract of $C$. hirsutus $(1000 \mathrm{mg} / \mathrm{kg}$, p.o.) treated mice. The serum glucose level was analyzed at $0,30,60$, and 120 min after drug administration.

Results: The aqueous leaf extract of $C$. hirsutus $(250,500$, and $1000 \mathrm{mg} / \mathrm{kg}$, p.o.) showed significant $(P<0.01)$ reduction of serum glucose level in alloxan-induced diabetic mice at 28th day. In oral glucose tolerance test, aqueous extract of $C$. hirsutus increased the glucose tolerance.
\end{abstract}

Conclusion: It is concluded that $C$. hirsutus has significant antihyperglycemic activity as it lowers serum glucose level in diabetic mice and significantly increases glucose tolerance.

KEY WORDS: Antidiabetic, glucose tolerance test, tana, vasanvel

\section{Introduction}

Diabetes mellitus is a metabolic disorder in which the body does not produce or properly use insulin. It causes disturbances in carbohydrate, protein, and lipid metabolism and complications such as retinopathy, microangiopathy, and nephropathy. ${ }^{[1]}$

The currently available oral antihyperglycemic agents for clinical use have characteristic profile of side effects. ${ }^{[2,3]}$ Management of diabetes with agents devoid of any side effects is still a challenge to the medical system. This has led to an increase in the demand for natural products with antihyperglycemic activity having less side effects. Indian traditional medicine is one of the richest medicinal systems among those available around the world. Long before the use of insulin, since the time of Charaka and Sushruta (sixth century BC, 400 BC), indigenous remedies have been used for the treatment of diabetes mellitus. In accordance with the recommendations of the $\mathrm{WHO}^{[4]}$ expert committee on diabetes mellitus, an investigation of antihyperglycemic agents of plant origin used in traditional medicine seems important. Many herbs and plant products have been shown to have antihyperglycemic action. ${ }^{[5-8]}$
The roots of Cocculus hirsutus (L.) Diels (Menispermaceae family) (locally called Vasanvel or Tana) have been mentioned as bitter, acrid, alterative, laxative, demulcent, and antiperiodic in fever, tonic, and diuretic. The juice of leaves coagulates in water and forms mucilage, which is used externally as a cooling and soothing agent in prurigo, eczema, and impetigo. ${ }^{[9]}$

The roots of $C$. hirsutus have been mentioned to possess antiinflammatory and analgesic properties. ${ }^{[10]}$ The objective of this study was to evaluate the antihyperglycemic activity of aqueous extract of leaves of $C$. hirsutus in alloxan-induced diabetic mice.

\section{Materials and Methods}

Animals

Swiss albino mice (National Toxicology Centre, Sinhagad Road, Pune) weighing between 30 and $35 \mathrm{~g}$ of either sex were used. Animals were housed under standard conditions of temperature $\left(24 \pm 2^{\circ} \mathrm{C}\right)$ and relative humidity (30-70\%) with a 12:12 light:dark cycle. The animals were fed with standard pellet diet (Chakan Oil Mills, Sangli) and water ad libitum. Animal handling was performed according to Good Laboratory Practice (GLP).

The Institutional Animal Ethics Committee (IAEC) of the 
Poona College of Pharmacy approved the proposal. Preparation of the extract

The plant $C$. hirsutus was collected from Katraj Ghat, Pune, and authenticated by an expert taxonomist of Agharkar Research Institute, Pune (museum sample no. WP-021).

The leaves were separated, shade-dried and powdered in a grinder. The powder was extracted successively with petroleum ether $\left(60-80^{\circ} \mathrm{C}\right)$ and absolute alcohol (ethanol) using Soxhlet apparatus. The residue was macerated overnight with water and filtered. The filtrate was dried on a tray drier at $60^{\circ} \mathrm{C}$ and was used for study purpose.

Preparation of the drug solution

An aqueous extract (100 mg) of leaves of $C$. hirsutus was dissolved in $10 \mathrm{ml}$ of distilled water to prepare stock solution of $10 \mathrm{mg} / \mathrm{ml}$. Appropriate dilutions were made to prepare lower doses for administration according to the body weight of mice.

Determination of $L D_{50}$ of $C$. hirsutus

For acute oral toxicity and $\mathrm{LD}_{50}$ determination, the Organization for Economic Co-operation and Development (OECD) guideline 425 $5^{[14]}$ was followed.

Induction of experimental diabetes

Diabetes was induced in Swiss albino mice of either sex by a single intravenous injection of aqueous alloxan monohydrate $(70 \mathrm{mg} / \mathrm{kg}$, i.v.) by the method described by Kameswara Rao et al. ${ }^{[11]}$ After 48 h, animals with serum glucose level above $200 \mathrm{mg} / \mathrm{dl}$ (diabetic) were selected for the study. The animals were allowed free access to tap water and pellet diet and maintained at room temperature in plastic cages.

Collection of blood and determination of serum glucose

Blood samples from mice were collected by retro-orbital puncture (ROP) technique. Serum glucose levels were determined by glucose oxidase and peroxidase method as described by Abdel-Barry et al. ${ }^{[12]}$ using commercially available kit (Accurex Biomedical Pvt. Ltd., Mumbai). Determination of serum glucose was done at $505 \mathrm{~nm}$ on Jasco UV-visible spectrophotometer (Model V530) and expressed as mg/dl. Effect of aqueous extract of leaves of $C$. hirsutus on serum glucose in alloxan-induced diabetic mice

The method described by Dunn et al. ${ }^{[13]}$ was adopted. The diabetic mice were fasted overnight and dived into five groups $(n=6)$. Group I-vehicle (distilled water, $10 \mathrm{ml} / \mathrm{kg}$, p.o.), group II-glyburide (10 mg/kg, p.o.), groups III-V-C. hirsutus extract (250, 500, and $1000 \mathrm{mg} / \mathrm{kg}$, p.o., respectively).

Study for the acute antihyperglycemic activity involved withdrawal of blood at $0,2,4,6$, and $24 \mathrm{~h}$ after administration of vehicle, glyburide, or aqueous extract of $C$. hirsutus. The blood samples were centrifuged and serum obtained to determine the glucose level.

Subacute study involved administration of vehicle, glyburide, or different doses of aqueous extract of $C$. hirsutus for a period of 28 days. Serum glucose levels were estimated on days 7, 14, 21, and 28. Mean change in serum glucose were calculated.

Effect of aqueous extract of leaves of C. hirsutus on body weight in alloxan-induced diabetic mice

During the study period of 28 days the mice were weighed daily and the mean change in body weight calculated.
Effect of aqueous extract of leaves of $C$. hirsutus on oral glucose tolerance test (OGTT)

Normal mice were divided into three groups $(n=6)$, viz, group I-only glucose $(2.5 \mathrm{~g} / \mathrm{kg}$, p.o.), group II-glyburide (10 mg/kg, p.o.), and group III-aqueous extract of $C$. hirsutus (1000 mg/kg, p.o.). The animals were fasted overnight before commencing the experiment. All mice were loaded with 2.5 g/kg, p.o., d-glucose solution (S.D. Fine-Chem. Ltd, Mumbai) after $0.5 \mathrm{~h}$ of drug administration. Blood samples were collected by the ROP method just prior to drug administration and 30, 60, and 120 min after glucose loading. Serum glucose level was measured immediately.

Statistical analysis

The results are expressed as mean \pm SD. Comparison between the groups was made by analysis of variance (ANOVA), followed by Dunnett's test as per suitability. $\mathrm{P}<0.05$ was considered significant.

\section{Results}

Effect of aqueous extract of leaves of $C$. hirsutus on serum glucose level in alloxan-induced diabetic mice

Single administration (single dose) of aqueous extract of leaves of $C$. hirsutus $(250,500$, and $1000 \mathrm{mg} / \mathrm{kg}$, p.o.) in diabetic Swiss albino mice, showed reduction in serum glucose level after 2, 4, and $6 \mathrm{~h}$ interval. Maximum reduction in serum glucose level was seen at doses of 250, 500, and $1000 \mathrm{mg} / \mathrm{kg}(38.33 \%, 32.72 \%$, and $16.54 \%$ decrease, respectively) after $6 \mathrm{~h}$ of $C$. hirsutus extract administration. Glyburide (10 mg/kg, p.o.) showed maximum reduction (44.33\% decrease) after $6 \mathrm{~h}$ [Table 1$]$.

On repeated administration (subacute treatment) of either vehicle or glyburide or aqueous extract of $C$. hirsutus for 28 days, a significant $(\mathrm{P}<0.01)$ decrease in serum glucose of the diabetic mice were seen at a dose of 250, 500, and $1000 \mathrm{mg} /$ $\mathrm{kg}$, p.o., in dose-dependent manner as compared with vehicletreated group. On the other hand, glyburide showed a significant $(\mathrm{P}<0.01)$ decrease in serum glucose at a dose of $10 \mathrm{mg} / \mathrm{kg}$, p.o., (58.57\% decrease) as compared with vehicletreated group.

Maximum activity of $C$. hirsutus was seen with a significant decrease $(\mathrm{P}<0.01)$ in serum glucose levels at the dose of $1000 \mathrm{mg} / \mathrm{kg}$ [Table 2].

Effect of aqueous extract of leaves of $C$. hirsutus on body weight in alloxan-induced diabetic mice

Administration of vehicle (distilled water, $10 \mathrm{ml} / \mathrm{kg}, \mathrm{p.o.}$.) in alloxan-induced diabetic mice resulted in gradual decrease in body weight during the period of 28 days. Aqueous extract of $C$. hirsutus in all doses except $250 \mathrm{mg} / \mathrm{kg}$ did not cause any decrease in body weight.

Effect of aqueous extract of leaves of C. hirsutus on OGTT in normal mice

The aqueous extract of leaves of $C$. hirsutus $(1000 \mathrm{mg} /$ $\mathrm{kg}$, p.o.) and glyburide (10 mg/kg, p.o.) significantly depressed the peak of serum glucose level at 30 min after glucose loading [Table 3].

Determination of $L D_{50}$ of aqueous extract of leaves of $C$. hirsutus in mice

Administration of a single dose of $C$. hirsutus $(175 \mathrm{mg} /$ $\mathrm{kg}$, body weight, p.o.) did not produce mortality in mice. The 
Table 1

Effect of $C$. hirsutus on serum glucose level in alloxan-induced diabetic mice (acute study)

\begin{tabular}{|c|c|c|c|c|c|}
\hline Groups & $\begin{array}{c}O h \\
(m g / d l)\end{array}$ & $\begin{array}{c}2 h \\
(m g / d l)\end{array}$ & $\begin{array}{c}4 h \\
(m g / d l)\end{array}$ & $\begin{array}{c}6 h \\
(m g / d l)\end{array}$ & $\begin{array}{c}24 h \\
(m g / d l)\end{array}$ \\
\hline Vehicle (distilled water,10 ml/kg) & $530.10 \pm 25.46$ & $534.70 \pm 26.46$ & $543.04 \pm 32.23$ & $552.43 \pm 33.88$ & $558.09 \pm 35.95$ \\
\hline Glyburide $(10 \mathrm{mg} / \mathrm{kg})$ & $569.84 \pm 48.67$ & $458.21 \pm 39.53^{*}$ & $419.00 \pm 38.06^{*}$ & $358.86 \pm 9.65^{*}$ & $521.71 \pm 83.96$ \\
\hline C. hirsutus $(250 \mathrm{mg} / \mathrm{kg})$ & $601.63 \pm 230.19$ & $577.03 \pm 28.04^{* *}$ & $438.73 \pm 69.57^{*}$ & $371.58 \pm 69.11^{*}$ & $597.57 \pm 28.59$ \\
\hline C. hirsutus $(500 \mathrm{mg} / \mathrm{kg})$ & $593.15 \pm 4.27$ & $587.20 \pm 16.32^{*}$ & $516.05 \pm 34.89^{*}$ & $398.82 \pm 47.64^{*}$ & $570.45 \pm 23.11$ \\
\hline C. hirsutus $(1000 \mathrm{mg} / \mathrm{kg})$ & $594.16 \pm 4.89$ & $592.93 \pm 7.99^{*}$ & $542.98 \pm 4.75^{\star}$ & $405.69 \pm 33.65^{*}$ & $568.58 \pm 47.28$ \\
\hline One-way & & 28.003 & 9.566 & 19.303 & 1.893 \\
\hline \multirow[t]{2}{*}{ ANOVA } & & 4,25 & 4,25 & 4,25 & 4,25 \\
\hline & & $<0.01$ & $<0.01$ & $<0.01$ & $<0.01$ \\
\hline
\end{tabular}

Values are mean $\pm S D, n=6$ in each group. ${ }^{*} \mathrm{P}<0.01 .{ }^{* *} \mathrm{P}<0.05$ when compared with vehicle-treated group (Dunnett's test).

Table 2

Effect of $C$. hirsutus on serum glucose in alloxan-induced diabetic mice (subacute study)

\begin{tabular}{|c|c|c|c|c|c|}
\hline Groups & $\begin{array}{c}\text { Day } 0 \\
\text { (mg/dl) }\end{array}$ & $\begin{array}{c}\text { Day } 7 \\
\text { (mg/dl) }\end{array}$ & $\begin{array}{l}\text { Day } 14 \\
\text { (mg/dl) }\end{array}$ & $\begin{array}{l}\text { Day } 21 \\
\text { (mg/dl) }\end{array}$ & $\begin{array}{l}\text { Day } 28 \\
\text { (mg/dl) }\end{array}$ \\
\hline Vehicle (distilled water, $10 \mathrm{ml} / \mathrm{kg}$ ) & $530.10 \pm 25.46$ & $574.38 \pm 16.09$ & $579.23 \pm 11.95$ & $593.95 \pm 29.34$ & $603.26 \pm 20.86$ \\
\hline Glyburide $(10 \mathrm{mg} / \mathrm{kg})$ & $569.84 \pm 48.67$ & $467.54 \pm 35.54^{*}$ & $397.61 \pm 42.99^{*}$ & $384.85 \pm 36.32^{*}$ & $286.25 \pm 54.23^{*}$ \\
\hline C. hirsutus (250 mg/kg) & $601.63 \pm 23.19$ & $457.33 \pm 15.71^{*}$ & $438.38 \pm 26.56^{*}$ & $404.33 \pm 32.70^{*}$ & $367.22 \pm 35.66^{*}$ \\
\hline C. hirsutus $(500 \mathrm{mg} / \mathrm{kg})$ & $593.15 \pm 4.27$ & $450.26 \pm 44.60^{*}$ & $392.14 \pm 47.03^{*}$ & $377.87 \pm 41.48^{*}$ & $365.98 \pm 41.55^{*}$ \\
\hline C. hirsutus $(1000 \mathrm{mg} / \mathrm{kg})$ & $594.16 \pm 4.89$ & $467.74 \pm 1.34^{*}$ & $340.40 \pm 39.67^{*}$ & $323.16 \pm 28.39^{*}$ & $300.31 \pm 48.86^{*}$ \\
\hline One-way & & 21.049 & 38.009 & 55.631 & 55.846 \\
\hline \multirow[t]{2}{*}{ ANOVA } & & 4,25 & 4,25 & 4,25 & 4,25 \\
\hline & & $<0.01$ & $<0.01$ & $<0.01$ & $<0.01$ \\
\hline
\end{tabular}

Values are mean $\pm S D, n=6$ in each group. ${ }^{\star} P<0.01$ when compared with vehicle-treated group (Dunnett's test).

\section{Table 3}

Effect of $C$. hirsutus on OGTT in normal mice

\begin{tabular}{|c|c|c|c|c|c|}
\hline Groups & Narmal & $0 \min$ & $30 \mathrm{~min}$ & 60 min & $120 \min$ \\
\hline Glucose (2.5\%, p.o.) & $124.90 \pm 18.46$ & $270.88 \pm 65.85$ & $374.64 \pm 69.44$ & $171.62 \pm 32.93$ & $138.72 \pm 34.78$ \\
\hline Glyburide $(10$ mg/kg) & $104.53 \pm 15.11$ & $182.17 \pm 55.05^{*}$ & $237.99 \pm 34.26^{*}$ & $164.71 \pm 12.88$ & $147.85 \pm 31.95$ \\
\hline C. hirsutus $(1000 \mathrm{mg} / \mathrm{kg})$ & $106.05 \pm 13.21$ & $328.92 \pm 30.62^{*}$ & $252.98 \pm 30.25^{*}$ & $172.31 \pm 33.45$ & $143.58 \pm 17.84$ \\
\hline One-way & & 4.270 & 4.693 & 5.421 & 9.149 \\
\hline \multirow[t]{2}{*}{ ANOVA } & & 4,25 & 4,25 & 4,25 & 4,25 \\
\hline & & $<0.01$ & $<0.01$ & $<0.01$ & $<0.01$ \\
\hline
\end{tabular}

Values are mean $\pm S D, n=6$ in each group. ${ }^{*} P<0.05$ when compared with vehicle-treated group (Dunnett's test).

animals were alive, healthy, and active during the observation period of 14 days. Use of AOT 425 software was made to obtain higher doses for $\mathrm{LD}_{50}$ determination as per OECD guidelines. In case of $C$. hirsutus, the computer program suggested doses 550, 1750, and $2000 \mathrm{mg} / \mathrm{kg}$. Results indicated that doses upto $2000 \mathrm{mg} / \mathrm{kg}$ were nonlethal. All animals were found to be alive, healthy, and active during the observation period of 14-day postadministration of highest dose. The computer program showed $\mathrm{LD}_{50}>2000$ $\mathrm{mg} / \mathrm{kg}$.

\section{Discussion}

The plant of $C$. hirsutus has been reported to contain essential oil, B-sitosterol, ginnol, ${ }^{[15]}$ glycosides, sterols, and alkaloids. ${ }^{[16]}$ Preliminary phytochemical analysis of the leaves showed presence of alkaloids, phenolic compounds, flavonoids, glycosides, and carbohydrates.

The alkaloids reported to be present in the plant are shaheenine, ${ }^{[17]}$ cohirsinine,$^{[18]}$ hirsutine, ${ }^{[19]}$ jamtinine, ${ }^{[20]}$ jamitine- $N$-oxide, ${ }^{[21]}$ cohirsine, ${ }^{[2]}$ corsitinine, ${ }^{[23]}$ and haiderine. ${ }^{[24]}$ The alkaloids present in the leaves of $C$. hirsutus 
Table 4

Effect of $C$. hirsutus on body weight $(g)$ in alloxan-induced diabetic mice

\begin{tabular}{|c|c|c|c|c|c|}
\hline Groups & Day 0 & Day 7 & Day 14 & Day 21 & Day 28 \\
\hline Vehicle (distilled water,10 ml/kg) & $32.00 \pm 1.41$ & $28.00 \pm 3.03$ & $26.67 \pm 2.42$ & $25.00 \pm 2.61$ & $23.33 \pm 2.34$ \\
\hline Glyburide $(10 \mathrm{mg} / \mathrm{kg})$ & $36.17 \pm 1.33$ & $34.37 \pm .88^{*}$ & $36.00 \pm 4.69^{*}$ & $36.33 \pm 5.85^{*}$ & $37.00 \pm 4.9^{*}$ \\
\hline C. hirsutus $(250 \mathrm{mg} / \mathrm{kg})$ & $33.17 \pm 2.04$ & $31.83 \pm 3.54$ & $31.00 \pm 4.24$ & $30.33 \pm 2.94$ & $29.50 \pm 2.43$ \\
\hline C. hirsutus (500 mg/kg) & $30.33 \pm 2.58$ & $31.17 \pm 3.49$ & $31.17 \pm 4.58$ & $32.00 \pm 3.69^{*}$ & $31.83 \pm 3.92^{*}$ \\
\hline C. hirsutus $(1000 \mathrm{mg} / \mathrm{kg})$ & $35.50 \pm 1.64$ & $33.33 \pm 2.66^{*}$ & $33.17 \pm 2.79^{*}$ & $34.00 \pm 6.19^{*}$ & $34.33 \pm 6.19^{*}$ \\
\hline One-way & & 11.840 & 14.629 & 0.05656 & 0.1474 \\
\hline \multirow[t]{2}{*}{ ANOVA } & & 2,25 & 2,25 & 2,25 & 2,25 \\
\hline & & $<0.05$ & $<0.01$ & $<0.05$ & $<0.05$ \\
\hline
\end{tabular}

Values are mean $\pm S D, n=6$ in each group. ${ }^{*} \mathrm{P}<0.05$ when compared with vehicle-treated group (Dunnett's test).

are D-trilobine and DL-coclaurine. ${ }^{[25]}$ The leaves also contain isotrilobine, (+)-syringaresinol and protoquericitol. ${ }^{[26]}$

Alloxan, a ß-cytotoxin, induces "chemical diabetes" in a wide variety of animal species including mice by damaging the insulin-secreting B-cells of the pancreas. Alloxan causes time- and concentration-dependent degenerative lesions of the pancreatic $\beta$-cells. The dose of alloxan required to produce diabetes varies with the species.

In the present study, the antihyperglycemic activity of aqueous extract of leaves of $C$. hirsutus was evaluated in alloxan-induced diabetic mice. Single-dose study with 250, 500 , and $1000 \mathrm{mg} / \mathrm{kg}$ showed significant $(\mathrm{P}<0.01)$ decrease in serum glucose level at 2, 4, and $6 \mathrm{~h}$. Continuous treatment with the aqueous extract of leaves of $C$. hirsutus $(250,500$, and $1000 \mathrm{mg} / \mathrm{kg}$ ) for a period of 28 days showed a significant decrease $(\mathrm{P}<0.01)$ in the serum glucose level in diabetic mice. Maximum reduction of serum glucose level occurred at the dose of $1000 \mathrm{mg} / \mathrm{kg}$, p.o.

There was a significant weight loss in the vehicle-treated diabetic mice, whereas treatment with the aqueous extract of leaves of $C$. hirsutus at the doses of 500 and $1000 \mathrm{mg} / \mathrm{kg}$, p.o., showed improvement in their body weights, indicating that the aqueous extract had beneficial effect in preventing loss of body weight of diabetic mice [Table 4].

Antihyperglycemic activity of methanol extract of roots of $C$. hirsutus is reported. Total alkaloid fraction prepared from methanol extract showed considerable antihyperglycemic activity in diabetic rats. Total alkaloids reduced the blood sugar level of diabetic rats significantly. Hence, the alkaloids in the roots of $C$. hirsutus have been reported to be responsible for the antihyperglycemic activity. ${ }^{[27]}$

It may be said that the aqueous extract of leaves of $C$. hirsutus decreased the serum glucose level and improved glucose tolerance owing to the presence of alkaloids. $\mathrm{LD}_{50}$ determination $(>2000 \mathrm{mg} / \mathrm{kg}$ ) indicated safety profile of the drug.

\section{Conclusion}

The aqueous extract of leaves of $C$. hirsutus has antihyperglycemic activity as it lowers serum glucose level in diabetic mice and significantly increases glucose tolerance.
The extract also prevents loss of body weight in diabetic mice.

\section{Acknowledgment}

The author would like to thank Dr. S. S. Kadam, Principal, Poona College of Pharmacy, Pune, India, for financial support, keen interest, and valuable guidance to carry out the work.

\section{References}

1. Rameshkumar K, Shah SN, Goswami DB, Mohan V, Bodhankar SL. Efficacy and toxicity of vanadium nicotinate in diabetic rats. Toxicol Int 2004;11:75-80.

2. Kameswara Rao B, Kesavulu MM, Giri R, Apparao Ch. Herbal Medicines: In the treatment of diabetes mellitus. Manphar Vaidya Patrika 1997;l:33-5.

3. Holman RR, Turner RC. Oral agents and insulin in the treatment of NIDDM. In: Pickup J, Willians G, editoris. Textbook of Diabetes Oxford: Blackwell; 1991.

4. The WHO Expert Committee on Diabetes mellitus. Technical Reports series 646. Geneva: World Health Organization; 1980.

5. Rai MC. A review on some hypoglycemic plants of India. Ancient Sci Life 1994;XIV:42-54.

6. Bailey CJ, Day C. Traditional plants medicines as treatment for diabetes. Diabetes Care 1989;12:553-64.

7. Mukherjee SK. Indigenous drugs in diabetes mellitus. J Diab Assoc India 1981;XXI:97-106.

8. Ajgaonkar SS. Herbal drugs in the treatment of diabetes a review. IDF Bulletin 1979;24:10-7.

9. Nadkarni AC. Indian Materia Medica Vol. I. $3^{\text {rd }}$ ed. Mumbai: Popular Prakashan; 1982.

10. Nayak SK, Singhai AK. Anti-inflammatory and analgesic activity of roots of Cocculus hirsutus. Indian J Nat Prod 1993;9:12-4.

11. Kameswara Rao B, Kesavulu MM, Giri R, Apparao Ch. Hypoglycemic and hypolipidemic effects of Momordica cymbalaria Hook. Fruit powder in alloxan-diabetic rats. J Ethnopharmacol 1999;67:103-9.

12. Abdel-Barry JA, Abdel-Hassan IA, Al-Hakiem MH. Hypoglycemic and antihyperglycaemic effects of Trigonella foenum-graecum leaf in normal and alloxan induced diabetic rats. J Ethnopharmacol 1997;58:149-55.

13. Dunn JS, Mc Letchie NG. Experimental alloxan diabetes in rats. Lancet 1943;2:384-7.

14. OECD: Guideline 425 Acute Oral Toxicity. Environmental Health and Safety Monograph series on Testing and Assessment No. 24. 2000.

15. Merchant JR, Naik RM, Hirwe SN. Chemical Investigation of Cocculus hirsutus (L.) Diels. J India Chem Soc 1962;39:411-6.

16. Das PK, Nath V, Gode KD, Sanyal AK. Preliminary phytochemical and pharmacological studies of Cocculus hirsutus Linn. Indian J Med Res 1964;52:300-7.

17. Rasheed T, Khan MN, Zhadi SS, Durrani S. Shaheenine: A new alkaloid from Cocculus hirsutus. Fitoterapia 1991;62:157-8.

18. Viquaruddin A, Tahir R, Shaista I. Cohirsinine, an alkaloid from Cocculus 
hirsutus. Phytochemistry 1991;30:1350-1.

19. Rasheed T, Khan MN, Zhadi SS, Durani S. Hirsutine: A new alkaloid from Cocculus hirsutus. Pak J Nat Prod 1991;54:582-4.

20. Viqaruddin A, Iqbal S. Jamtinine an alkaloid from Cocculus hirsutus. Phytochemistry 1993;33:735-6.

21. Viqaruddin A, Atta-U-Rahman, Tahir R, Habib-Ur-Rehman. Jamtine- $N$ oxide: a new isoquinoline alkaloid from Cocculus hirsutus. Heterocycles 1987;26:1251-5.

22. Viqaruddin A, Atta-U-Rahman, Rasheed T, Habib-Ur-Rehman, Khan AQ. Cohirsine: A new isoquinoline alkaloid from Cocculus hirsutus. Tetrahedron 1987;43:5865-72.
23. Viquaruddin A, Iqbal S. Cohirsitine, a new isoquinoline alkaloid from Cocculus hirsutus. Fitoterapia 1992;63:308-10.

24. Viqaruddin A, lqbal S. Haiderine, a new isoquinoline alkaloid from Cocculus hirsutus. Nat Prod Lett 1993;2:105-9.

25. Jagannadha Rao KV, Ramachandra RL. Chemical examination of Cocculus hirsutus (Linn) Diels. J Sci Ind Res 1961;20:125-6.

26. Viqaruddin A, Tahir RJ. Studies on the chemical constituents of Cocculus hirsutus. Chem Soc Pak 1986;8:537-40.

27. Satyanarayana K, Mangathayaru V, Shreekanth J, Venkateswarlu V, Kokate CK. Studies on hypoglycaemic and cardiotonic effects of roots of Cocculus hirsutus. J Pharmaceutical Sci 2001;63:30-5.

\section{Unleash the} power of your literature search.......

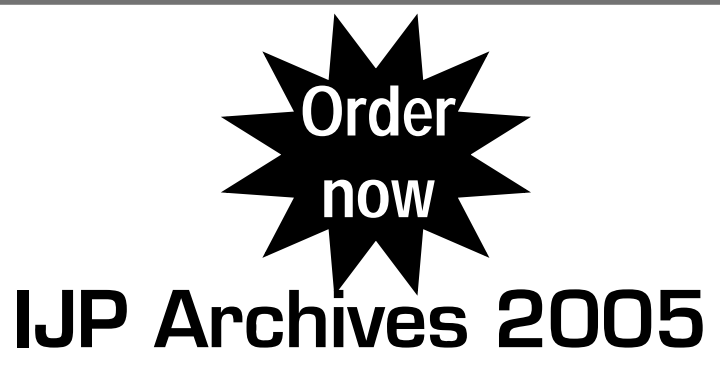

\section{Rs. 500/- for IPS members}

Rs. 2000/- for Libraries \& Educational Institutes in India
O Full articles in PDF format from 1969-2005
O Versatile search facility
O Easy installation
O User friendly interface
O In-built help and instructions

For details please contact: $\quad$ The Chief Editor - IJP

Department of Pharmacology,

JIPMER, Pondicherry-605 006.

E-mail: ijp@jipmer.edu 